\title{
KAABA VERSUS RINGTHEATER - THE HOLY CROSS CHURCH - WARSAW'S POGROM: TWO WORLDS AND THREE TRAGEDIES IN MODLITWA (1882) BY CYPRIAN NORWID
}

Among the literary works written by Cyprian Norwid during the last years of his life there are ones that have not been extensively discussed yet. ${ }^{1}$ One example is a short prose piece titled Modlitwa [Prayer], which reads:

- - - Do meczetu w Kaaba o godzinie modlitwy południowej wbiegł zapamiętalec i zawołał: „Gore! -- - dach świątyni w płomieniach!! --”

Parę Greków podróżnych i Europejczyków wraz uciekło - - żaden Arab głowy nie obrócił ani ziarn różańca nie pomylił, albowiem na południową przyszedłszy modlitwę, tęż pełnili... I po skończeniu jej powstawszy z ziemi szli spokojnie z zwykłą powagą - - i rozeszli się.

Przypadku żadnego być nie mogło w domu modlitwy... gdzie Arabowie nie przychodzą ,pod wrażeniem Teatru-wiedeńskiego" 1882 (PWsz VI, 645) $^{2}$

1 'In the laconic, aphoristic 'parable' Modlitwa, written after the tragic fire at the Viennese theatre, where many people died, the poet expressed his deep respect for the Muslims' unshaken faith in the power of prayer and Providence - the kind of faith that excludes from their historiosophic horizon any chance or absurdity." R. GADAMSKA-SERAFIN, 'Lud 'Koranu'-lud 'Ewangelii'. 'Norwid o genezie islamu i historii relacji chrześcijańsko-muzułmańskich, "Tematy i Konteksty” 2016, no. 6 (11), pp. 438-439. See also: IDEM, Świat arabsko-muzułmański w dziełach Norwida. Inspiracje i źródła, [in:] Kulturowy wymiar twórczości Norwida, eds. J.C. Moryc OFM, R. Zajączkowski, Lublin 2016, pp. 39-83. Norwid's inedited "Mahomet - Koran" is analysed by Piotr Chlebowski in: Protestantyzm Bizancjum - Islam. Uwagi na marginesie lektury trzech notatek, [in:] IDEM, Polihymnia CN 2. Studia i szkice interpretacyjne, Lublin 2019, pp. 327-342. Studies of Islam in Norwid (and in Polish literature) have so far neglected the fundamental work by Józef Pelczar: Ziemia Święta i islam czyli Szkice z pielgrzymki do Ziemi Świętej, którą w roku 1872 odbyt i opisał Józef Pelczar, cz. 2: Islam (Lwów 1875).

${ }^{2}$ Modlitwa was first published posthumously in: C. NorwID, Wszystkie pisma, ed. Z. Przesmycki, vol. 5: Proza epicka, Warszawa 1937 [1938], p. 187. 
[-- - An overzealous man stormed into the Kaaba Mosque at the time of the noon prayer, shouting "Fire! - - - the roof of the temple is on fire!! - -" Several travelling Greeks and other Europeans fled instantly - - but no Arab would turn his head or mistake a single bead in the rosary, for they came to pray at noon and this is what they did... After finishing their prayers, they rose calmly and went separate ways - - with the usual seriousness. Nothing can happen by chance in the house of prayer... where Arabs never fall "under the impression of the Viennese Theatre" 1882]

The manuscript of the poem contains the date at the end of the text. ${ }^{3}$ This hint has been aptly interpreted in the poem's historical context by Juliusz Wiktor Gomulicki, who indicated the circumstances in which the piece was composed, and defined its genre, concluding that this "miscellaneous, half-aphoristic piece was written most probably in January 1882, when Norwid may have still been under the impression of the fire in Vienna, which consumed the famous Ringtheater in December 1881, burying crowds of spectators in the rubble after they trampled each other in an attempt to reach the exit." ${ }^{4}$ Still, the genre attribution is debatable, while the genesis of this piece could be hypothetically specified further by pointing out other circumstances.

The tragedy occurred on Thursday, 8 December 1881 . For many people at that time, including first-hand witnesses, it was important that the fire broke out on the Feast of the Immaculate Conception, a holiday greatly respected by the Catholic Habsburg monarchy, and a "young" feast that was established only seventeen years earlier, on 8 December 1854 by Pope Pius IX in the bull Ineffabilis Deus. ${ }^{5}$

3 "The manuscript, now lost, used to belong to Ludwik Nabielak, whose papers were donated by his widow to Wacław Gasztowtt. Signed: Cyprian Norwid / 1882. [...] The text follows the edited version prepared for publishing." J.W. GoMULICKI, "Metryki i objaśnienia," [in:] C. NoRWID, PWsz VII, 636. One decision made by Gomulicki is debatable: the use of italics in the phrase "pod wrażeniem teatru-Wiedeńskiego" was rendered using spaced-out print as "p o d w ra ż e n i e m Teatru-wiedeńskiego." If we deem the original printing as identical with the manuscript, Gomulicki's decision violates the (inferred) intention of the poet to make the phrase "pod wrażeniem Teatru" a higher-order unit (in terms of meaning) and the bit "-wiedeńskiego" its complement, a concretization set in real time and space, referring to a specific event and Norwid's literary reaction to it.

4 J.W. Gomulicki, "Metryki i objaśnienia," [in:] C. Norwid, PWsz VII, 636.

5 “On 8 December 1854, the Immaculate Conception of the Blessed Virgin Mary received dogmatic confirmation. [...] through this dogma, the Church did not curb the imaginativeness of thought but rather helped it to grasp the truth by enlightening the mind and removing every shade of doubt, which could only yield before the light of Church's unerring solemnity. Focusing our will on acknowledged truth and experiencing the salutary effects of the Immaculate Conception of the Blessed Virgin Mary, our moral freedom finds new support in its effort to abide by its holiness till the very end." REV. W. GRZEGORZEK, Dogmat Niepokalanego Poczęcia Najświętszej Maryi Panny. Rozprawa historyczno-dogmatyczna, Tarnów 1855, p. 11, 194. 
It was also a controversial holiday because in the increasingly secularized Europe, including Vienna itself, opponents and critics of the Church argued that it contradicted the spirit of the epoch by favouring revelatory truths over the primacy of reason, science, and progress.

The fire started in the evening, around 18.45 , shortly before the second performance of Jacques Offenbach's The Tales of Hoffmann ${ }^{6}$, which premiered on the previous day, i.e. on 7 December. $^{7}$ The theatre itself was erected as opéra comique in the years 1872-1874 in 7 Schottenring Street. It was one of the more impressive buildings of this type in the Empire and in Europe. In Vienna itself, it competed with the Hofoper, which was built in 1869 (Das k. k. Hof-Operntheater). Due to spatial limitations, the building was very high, featuring five storeys of galleries and balconies, accommodating as many as 1,700 viewers, almost the same as the Hofoper. The name Ringtheater was given to the place in 1878 when its repertoire was revamped as a variété type of stage presenting comical operas, operettas, and light theatre.

The fire was caused by a malfunctioning gas lighting installation and quickly spread all over the edifice, consuming it almost completely by midnight. As one of the greatest fires recorded in the Austrio-Hungarian Empire in the nineteenth century, it killed many people: 384 in accordance to official data and 449 according to press reports, while later studies speak of as many as one thousand victims. ${ }^{8}$ The actual number was difficult to establish because many corpses burned to ashes. ${ }^{9}$ The Ringtheater's Director, the exceptional artist Franz Ritter von Jauner, was sentenced to three years of prison, but the Emperor pardoned him several weeks

${ }^{6}$ Offenbach's operetta in fact premiered (already after the composer's death) in OpéraComique in Paris on 10 February 1881, but this version was shortened, comprising only two acts. The Viennese premiere on 7 December, one day before the fire, was based on a fuller (yet still incomplete) version of the work. The orchestra was conducted by Joseph Hellmesberger Junior. The second performance, scheduled for 8 December, could not take place due to the fire, which also consumed all the relevant materials. See: M. DiBbern, The Tales of Hoffmann. A Performance Guide, Hillsdale 2002, p. XX, 227.

${ }^{7}$ For an encyclopaedic discussion of the fire, based on sources, see: Ringtheaterbrand, https://www.wikiwand.com/de/Ringtheaterbrand, which contains a sizeable bibliography. See also: http://www.viennatouristguide.at/Friedhoefe/Zentralfriedhof/Opfergraeber/1881_ringtheater.htm. The first performance was attended, among other people, by Johann Strauss, the Younger; see: R. Traubner, Operetta. A Theatrical History, New York 2003, p. 118.

${ }^{8}$ See: L. EISENBERG, Grossesbiographisches Lexikon der deutschen Bühne im 19. Jahrhundert, Leipzig 1903, p. 476 (entry: "Jauner Franz Ritter von") - "unheilvollste Tag in der Theatergeschichte Wiens."

9 In order to identify the victims, a new method in forensic medicine was used, namely dental examination. See: J. Mikoletzky, Der Brand des Wiener Ringtheaters 1881 und die Folgen, "Ferrum. Nachrichten aus der Eisenbibliothek" 69 (1997), pp. 58-68. 
after the incident. Political responsibility was taken by the city mayor Julius Newald, who resigned. ${ }^{10}$

News of the tragedy spread through telegraph agencies all over Europe on the same day, while special dispatches and longer articles were published in the press the day after and later. A detailed report from the place of tragedy was published on Friday, 9 December, by the Viennese Neue Freie Presse ${ }^{11}$, becoming the key source of information for many foreign periodicals. The topic continued to be debated in the press until late December. The Viennese biweekly Messager de Vienne, edited and published by Bronisław Wołowski, supported the international relief fund, which was endorsed for example by the French writers Victor Hugo and Alphonse Daudet. ${ }^{12}$ In the entire Empire, including Galicia, and throughout Europe, charity events were organized to raise money for the victims and their families, while memorial services were held in churches.

The atmosphere at that time, marked by mourning and reflection on the spiritual aspects of the catastrophe, was well rendered by the poet Aureli Urbański, who spoke from the stage of a theatre in Lviv, addressing the mournful capital of the Empire using its ancient Latin name: "Over the spires of the cathedral in the silent Vindobona / A black pall spreads its wings. / [...] The shout: 'Fire!' [...] / Weep, Vindobona! [...]. / Today, you are a sarcophagus of mute pain, / Over which humanity has wrung its hands." ${ }^{\prime 3}$ Notably, some time after the tragedy, Viennese authorities commemorated the victims by erecting a mausoleum in the Central Cemetery (Zentralfriedhof). Its centrepiece consists of Vindobona bewailing her children; she is the personification of the city, which was once a Roman castrum at the Danube. ${ }^{14}$

The tragedy at Ringtheater was not an isolated event. On the contrary, the fire exacerbated an already tragic death toll recorded that year. The series of disasters was started by a fire in Munich on 18 February (nine dead), in Nice on 23

${ }^{10}$ See: J. SACHSLEHNER, 365 Schicksalstage. Der Gedächtniskalender Österreichs, WienGraz-Klagenfurt 2012, p. 425.

${ }^{11}$ See: "Brand des Wiener Ringtheaters," Neue Freie Presse 1881, no. 6209, pp. 2-3. For images (including a photograph of the interior from 1880, and a coloured lithography presenting the fire from 1882) see: Historische Bilder zu Ringtheater, https://austria-forum.org/af/Bilder_und Videos/Historische_Bilder_IMAGNO.

${ }^{12}$ See: "Wiener Allgemeine Zeitung", no. 649 (18 December 1882), p. 7; Wohltätigkeitsacte, "Neue Freie Presse", no. 6220 (20 December 1882), p. 6.

13 A. UrbaŃski, Prolog, wygloszony na scenie lwowskiej dnia 19 grudnia 1881 podczas przedstawienia danego na rzecz ofiar pożaru w wiedeńskim Ringtheater, [in:] Utwory poetyczne, Lipsk 1884. In 1884, Urbański published a translation of The Tales of Hoffmann in Lviv.

${ }^{14}$ See: Opfer des Ringtheaterbrandes 1881, http://www.viennatouristguide.at/Friedhoefe/ Zentralfriedhof/Opfergraeber/o_02_1881ring.htm. 
March (ca. two hundred dead), in Prague on 11 August (at the National Theatre, no victims). ${ }^{15}$ Two weeks after the catastrophe in Vienna, a fire broke out in the Vaudeville Theatre in Paris. Towards the end of the year, panic seized the crowd upon news of an alleged fire in London's New Grecian Theatre. Finally, on 18 January 1882 , fire spread through the opera theatre in Rotterdam. ${ }^{16}$

As confirmed by Norwid's Modlitwa, the Viennese tragedy continued to resonate socially for many months. However, a closer examination of the poem and its structure of ideas allows us to discern references to two real events that provided the poet with background to his story (though hidden by poet and passed over in silence) and were closely related to the fire itself.

These two events - hailed by the press as "Warsaw catastrophes" - were the tragic outbreak of panic in the Holy Cross Church in Krakowskie Przedmieście during High Mass on the first day of Christmas, and the related anti-Semitic pogrom in the days 25-27 December $1881 .^{17}$

Norwid knew about these events probably from the article "Kilka słów z powodu warszawskich rozruchów" published in "Kurier Paryski" on 15 January 1882. ${ }^{18}$ This broad report, based on information from "national dailies," was most likely written by the editor and publisher of the biweekly - Adolf Reiff. His authorship would be also confirmed by the fact that in the next issue (dated 1 February) he signed the article "Do braci Polaków wyznania mojżeszowego," where he

${ }^{15}$ Upon news of the fire at the National Theatre in Prague (Narodni divadlo), Maria Konopnicka wrote a moving poem “Gore!” [“Fire!”]. See: IDEM, Poezje, ed. J. Czubek, Warszawa [1915], vol. 2, pp. 104-106.

${ }^{16}$ See: A. TuszyŃSKA, 'Teatr się pali!... ' O czterech pożarach Teatru Narodowego, [in:] O teatrze i dramacie. Studia - przyczynki - materiaty, eds. E. Krasiński et al., Wrocław 1989, pp. 337-340. Complete documentation is provided by August Fölsch in: Theaterbrände und die zur Verhütung derselben erforderlichen Schutz-Massregeln, Ergänzungs-Heft mit einem neuen Verzeichniss von 108 abgebrannten Theatern, Hamburg 1882 (first published in 1878). At that time, the Polish author Celestyn Zyblikiewicz published two studies devoted to preventing fires like the one in Ringtheater (the first one anonymously): Keine Theaterkatastrophen, kein Feuertod, kein Massengrab in Theatern mehr!, von einem Landmann, Wien 1882; Als Andenken an die Traurige Brandkatastrophe im Wiener Ringtheateram 8 Dezember 1881. "Keine Theaterkatastrophen, kein Feuertod, kein Massengrab in Theatern mehr!' Denkschrift des Coelestin Zyblikiewicz, Erfinder des Bauplans für feuersichere Theater, nach welchemals das Erste das Wiener Burgtheater aufgebaut worden ist, Kolomea 1898. For more information on this author see: B. BuRDZIEJ, Nowa Judea (1887) Celestyna Zyblikiewicza. Polski projekt państwa żydowskiego a dzieło Theodora Herzla (1896), [in:] Prus i inni: prace ofiarowane profesorowi Stanisławowi Ficie, eds. J.A. Malik, E. Paczoska, Lublin 2003, pp. 449-464.

${ }^{17}$ See: F. Golczewski, Polnisch-Jüdische Beziehungen 1881-1922. Eine Studie zur Geschichte des Antisemitismus in Osteuropa, Wiesbaden 1981.

18 "Kurier Paryski", no. 9 (15 January 1882), pp. 2-3. 
asks his compatriots to "examine their conscience" and urges Jews to consider the harm they may have done to the Polish society.

Consider the opening passages from the article, featuring a concise and quite credible (not necessitating double-checking with other sources) reconstruction of the "Warsaw unrest":

National dailies have widely described the sad incident at the Holy Cross Church and the riots started by common people in Warsaw during the Christmas season.

The church was filled with worshippers. Those who could not enter were standing out in the street. The priest was celebrating Mass at the high altar when the panic spread through the crowd at the door. Someone shouted "Fire! Fire!" and many people panicked because they would remember the martyr's death of several hundred [!] people in the blaze that consumed the Viennese Ringtheater on 8 December 1881 . They started crowding at the doors and outside the church on the steps, where especially at the last steps the crowd grew dense, becoming an intense throng in which everyone kept starting and pressing on others. Twenty-nine people suffocated, while more than fifty were severely injured. The victims were mostly women and children - only a few men died. The firefighters arrived quickly and prevented further tragedy. [...]

The sight of dead bodies was terrifying. The common people of Warsaw are quite sensitive to misfortune. Someone spread the gossip that this tragedy was the fault of the Jews: that some Jewish cutpurse was caught red-handed and started crying "Fire!" to save himself and escape. Common people do not seek to find out the truth and believe in hearsay, so they accepted the version that blamed the Jews and vented their outrage against them.

Outrage grew with every minute and, under its influence, a group of adolescents and workers decided to avenge the death of so many people before the church by retaliating against Jewish restaurants, shops, and apartments. Barrels of vodka were rolled out into the streets and spilled into the gutter, dishes were broken and furniture smashed, while various goods were thrown out into the mud. If they saw a cross or holy pictures, they would spare the flat. Many Jews placed their belongings and valuables in Christian homes because educated people would condemn violence and try to protect the Jews, which could have succeeded if the government allowed them to intervene and set up guard.

Assaults continued for three days. Some forty streets were ravaged as if Tatars passed through there. One thousand Jewish bars and shops were destroyed in around four hundred houses. Dazed with revenge and holiday carousal, the mob branched off into groups exploring various streets and destroying Jewish possessions. Here and there a Jew would be beaten up, but no murders were committed, and there was relatively little robbery or plundering. If it had not been for the priests, perhaps the situation would escalate, causing assaults to become much more dangerous, and perhaps leading to casualties.

Already in the church, a clear-headed priest who celebrated the Mass at the high altar stopped the panic from spreading in the crowds. He lifted the monstrance and everyone fell to their knees; then, the organs started playing and the song muffled the screams coming from outside. In this way, prayer saved the faithful in the church. It was already calm inside when the above-mentioned events unfolded outside. What would happen if everyone suddenly rushed to the doors? ${ }^{19}$

19 Ibid. 
The above constitutes around one third of the entire article. Norwid could have known this report, which is confirmed by a remark he made in a letter to Leonard Rettl: "I have leafed through almost all issues of "Kurier Paryski" [...]." ${ }^{20}$ On this basis it is possible to assume that Modlitwa was written most probably shortly after 15 January, before the article "Żydy i mechesy" [Jewes and Converted Jews] from June 1882, which contains allusions to pogroms (in Warsaw and earlier in Russia, which started in the summer of 1881). ${ }^{21}$

The hypothesis that the article from "Kurier Paryski" informed the poem Modlitwa justifies quoting the former in full, but this is not necessary to demonstrate the relation between the story in Norwid's piece and the actual events that constitute the following sequence: fire at the Viennese theatre - panic in the Holy Cross Church - the pogrom in Warsaw. In Norwid's poem, however, this sequence is not repeated, but draped as a parable set in another temple of another religion, outside of the current context. The key word in Modlitwa is "przypadek" [accident] since it reveals the poem's condensed "contents" and the spiritual meaning of the three catastrophes, which are aligned in a cause-and-effect chain and are seen not from the perspective of a journalist but in the mind's eye of one seeking truths hidden from practical reason. This word allows the poet not only to bring forth the three specific tragedies but also to "open" the poem, parabolically, to every other tragedy rooted in departure from God and His will in a shift towards "worldly" values.

The influence of the Warsaw events on Modlitwa is also confirmed by analysis of this poem. As a parable, the story told in it carries a specific moral message. Norwid develops his parable on the basis of the three aforementioned real events (one in Vienna, two in Warsaw), but in order to give his piece a more universal meaning he set it outside the original cultural context. The Arab world where the story unfolds adds more than just local colour meant to draw the attention of readers with its exotic character. The poet's choice was in fact motivated both artistically and in terms of ideas.

Reaching out to Arab culture, Norwid opposes the negative stereotypes that prevailed in Europe at the time with regard to the "followers of Muhammad" and involved "mocking the Quran," as noted already in 1850 by Edmund Chojecki

${ }^{20}$ PWsz X, 167. According to Gomulicki, this letter was written "either in late February or early March" of 1882 (ibid., p. 270). Incidentally, in the autumn of 1881 "Kurier Paryski" refused to publish a poem by Norwid, a fact which he learned about from the editor's trite note in the response section in the issue dated 1 October. See: PWsz X, 270. It cannot be ruled out that Norwid attempted to publish in "Kurier" both Modlitwa and the later article "Żydy' i mechesy" (written in June 1882).

${ }^{21}$ The links between this text and Modlitwa are not noted by M. Inglot in the article Nad artykutem Cypriana Norwida 'Żydy i mechesy', "Prace Polonistyczne” 58 (2003), pp. 167-178. 
in a letter to the Polish poet. ${ }^{22}$ In this poem, Islam, along with its sanctuary, the mosque in Mecca, and the faithful who do not stop their prayers for any "secular" reason, symbolizes religion, and more specifically faith as its expression that has not been secularized under the influence of apparent "worldly" values. Norwid seems to be quite close in his view to one contemporary scholar, who argues that in Islam God demands from the worshippers

[...] absolute obedience and submission to His will. The word islam means subjugation to God. Consequently, Islam requires - as its primary principle - not only that God is not connected with anything or anyone, but also that His followers obey only Him: anyone who allows their passions, desires and interests to determine their actions becomes guilty of heresy and polytheism, just like the ones who follow reason and personal convictions $[\ldots] .^{23}$

The distribution of roles in Norwid's parable confirms this conjecture. The fervent person who runs into the mosque and warns the praying that a fire broke out is not specified or characterised in the text. Nevertheless, this figure does not require any detailed presentation (it would not even be helpful), because his appearance is meant to indicate the danger itself, to which the people gathered in the temple react. It is their different responses that directly influence the moral assessment of the event.

Let us consider how Norwid differentiates the roles of the "actors" in his parable. On the one hand, there are travellers, Greeks and other Europeans, who flee from the mosque in fear of danger. On the other, however, there are Arabs, who keep praying, not even hearing the warning at all while in deep contemplation, or ignoring it because it would distract one from God, who should dominate the prayer.

The former, who are afraid for their lives (and for worldly matters in general, as a deeper interpretation would suggest) and regard the religious ritual as a spectacle, seem to resemble those attending the Mass in Warsaw, who - "under the impression of what happened in the Viennese theatre" - panicked and trampled on their neighbours, contributing to the start of the pogrom (carried out by others).

Still, Norwid does not offer us a text that feels like a reportage or a column. Although he is suggesting an analogy, it is at the same time softened by the fact that those attending the prayers have more universal features. Their identity - Greek or other European - would suggest that what is at stake is not ethnic differentiation (after all, Greeks are Europeans, too) but religious contrast, specifically one

${ }^{22}$ E. CHOJECKI, List do Cypriana Norwida, z Kairu, 25 października 1850, after: PWsz VIII, 497.

${ }^{23}$ R. Arnaldez, Jeden Bóg, [in:] F. Braudel et al., Morze Śródziemne. Przestrzeń i historia. Ludzie i dziedzictwo, trans. M. Boduszyńska-Borowikowa, B. Kuchta, A. Szymanowski, Warszawa 1994, p. 153. 
between Eastern and Western Christianity. (It remains another matter for interpretation to understand their presence in the Great Mosque of Mecca ${ }^{24}$ - a Muslim temple, where they arrive merely as travellers, not to pray, although it is the time of the noon prayer).

The second group of people attending the events in the temple are Arabs, followers of Islam. Their attitude is treated by Norwid as an example of true devotion to God, to the purity of heart and cult, giving us a sense of the inviolable character of holy sites and religious duty - a measure against which readers ought to judge Christians - travelling Greeks or Europeans - and perhaps even themselves.

The arbitrariness of the parable, entailed by this genre, dismisses all discussion: we have to believe that the Greeks and Europeans fled in fear of death and that no Arabs interrupted their prayer. The arbitrariness of this story decides about

${ }^{24}$ A detailed description of Mecca and Kaaba was available to Polish readers in 1881 thanks to Stanisław Strojnowski: "In the southern part of the city, where the valley is the broadest, there rises a huge mosque, the foremost one in the Islamic world, hosting the famous Kaaba, which gives the temple its significance. The mosque has four wings, encompassing a rectangular courtyard, 250 steps long and 200 steps wide. It is surrounded with rows of columns. Seven paths covered with stone slabs lead towards the Kaaba in the middle. It is a small, stone building, eighteen steps long, fourteen steps wide, and around forty feet high. Muslims say that it was built by Abraham, and that his son Ishmael delivered stones to erect it, which miraculously emerged from the earth thanks to God's omnipotence, already hewn as cubicles. The roof over Kaaba is completely flat, which makes it look like a cubicle from afar. In the north-eastern corner there lies the famous black stone, which is four or five feet high. As Muslims claim, it comes from heaven and was given to Abraham by Archangel Gabriel as a token of God's special grace; further, it used to be clean and transparent, but due to being touched by an impure woman it became black and opaque. The stone is worn away and smoothed due to constantly being touched and kissed, which makes it impossible to properly acknowledge its properties. [...] Pilgrims who enter the mosque and see the holy building beyond the columns for the first time have to say a special prayer and fall on the ground four times, thanking God for allowing them to fortunately visit the holy site. Then one takes one of the seven paths, but before approaching the Kaaba it is necessary to leave one's shoes under the pulpit, where sermons are delivered on holidays. After one stands in front of the black stone, one should once again fall on the ground four times and touch the stone with the right hand. Then, one circles the Kaaba seven times, beginning from the right side: the first three times at a stepped-up tempo, imitating the prophet, who ran three times around the Kaaba when his enemies spread lies that he fell gravely ill. After each round one says the prescribed prayers, after which it is necessary to kiss the black stone and then another one. At the end, pilgrims approach the Kaaba once again between the black stone and the main doors, holding the latter close to their breasts and asking God, with arms spread wide, to forgive their sins." S. STROJNOwsKi, Ziemia i jej mieszkańcy. Opisy malownicze krajów, ludów i obyczajów; z najcelniejszych autorów ojczystych i cudzoziemskich, oraz własnych prac, vol. 1, Warszawa 1881, pp. 145-146; a figure on p. 144 shows the Great Mosque of Mecca (in the first edition published in 1877). 
the power of the parable, its persuasive effect, and primarily the truthfulness of its moral message.

Norwid does not render Arab realities with mimetic faithfulness - in this poem they are merely vehicles of meanings developed in the parable, which aims to contrast different attitudes in order to deliver a moral message that cannot be questioned.

Phrases like "the mosque in Kaaba," technically incorrect (since Kaaba, the holy site of Islam and its sanctissimum, does not host a mosque, but is itself located in the outer courtyard of one), are only meant to invoke the holy space of Muslims. Other themes are also introduced by Norwid not to faithfully render the local colour, but rather to serve as signs that could function equally well in Arab culture and in Christian Europe, which the parable contrasts. The noon prayer, during which the faithful say the beads, is an image that can be understood by both Christians and Muslims. ${ }^{25}$ The passage that speaks about praying with a rosary ("[...] żaden Arab głowy nie obrócił ani ziarn różańca nie pomylił, albowiem na południową przyszedłszy modlitwę, tęż pełnili..." [no Arab would turn his head or mistake a single bead in the rosary, for they came to pray at noon and this is what they did...]) plays a crucial role in terms of ideas as a telling counterpoint to the "secular" behaviour of those who did not come to pray and fled the temple. No Muslim would mistake the beads or the names of God ascribed to each of the ninety-nine beads. ${ }^{26}$ The fullness of prayer $^{27}$ - as Norwid suggests - consists in focusing entirely on God regardless of circumstances, including warnings of fire or events at the foundation of the discussed poem.

${ }^{25}$ The role of the rosary in Norwid's works is discussed by Rev. Antoni Dunajski in: Semantyczne funkcje obiektów sakralnych i paramentów liturgicznych w pismach Norwida, [in:] Norwidowski świat rzeczy, eds. P. Abriszewska, G. Halkiewicz-Sojak, I. Dobrzeniecka, D. Wojtasińska, Torun 2018, p. 179. The author does not note a Muslim rosary in the poet's works.

${ }^{26}$ The theme of the rosary appears in Byron's The Corsair: "Within the Haram's secret chamber sate / Stern Seyd, still pondering over his Captive's fate; / His thoughts on love and hate alternate dwell, / [...] His only bends in seeming o'er his beads, / But only views his victim as he bleeds" (Canto 3, Part V). G.G. BYron, The Complete Works of Lord Byron, vol. 4, Paris 1835 , p. 259 . Online: https://books.google.pl/books?id=bCJNAAAAcAAJ\&lpg=PA259 \&ots $=$ Br1ffVDTnA\&dq $=$ Within $\% 20$ the $\% 20$ Haram $\%$ E2 $\% 80 \% 99 \mathrm{~s} \% 20$ secret $\% 20$ chamber $\% 20$ sate\&pg $=\mathrm{PP} 13 \# \mathrm{~V}=$ onepage $\& \mathrm{q} \& \mathrm{f}=$ false $($ accessed 25 January 2021$)$. In the footnote we read that the poet refers here to "[t] he comboloio, or Mahometan rosary" whose "beads are in number ninetynine" (ibid.). See also the entry "Tespih (tesbih, taspih)," [in:] J. DANECKI, Kultura islamu. Stownik, Warszawa 1997, p. 164.

${ }^{27}$ Cf. J. Woroniecki, Pelnia modlitwy. Studium teologiczne dla inteligencji. Zadania, składniki i własności modlitwy, Poznań 1934. 
This parable expresses an idea that permeates most of Norwid's works: poems, prose pieces, dramas, and also private correspondence. He would condemn all falsification of human attitudes towards others, and seek patterns of an authentic approach based on acknowledging religious duties that we have in relation to other people.

The choice of an Arab setting ${ }^{28}$ can be also regarded as a reference to the Enlightenment tradition of stories, legends, and fairy tales derived from the literature of the Muslim Orient. This tradition was cultivated by the Romantics, including Mickiewicz and Słowacki (the latter's protagonist Wacław Rzewuski "visited the Kaaba with Muslim prayer, / And saw the Prophet's tomb" ${ }^{29}$ ). In an earlier poem titled "Stolica" [Capital] Norwid also speaks of an Arab who rises above the crowd thanks to his dignified attitude:

Idzie Arab, z kapłańskim ruszeniem głowy,

Wśród chmurnego promieniejąc tłoku;

Biały, jak statua z kości słoniowéj:

Pojrzę nań... wytchnę oku! (Stolica, PWsz II, 39)

[ - An Arab walks, with the nod of a cleric's brow,

Radiant amid the sullen crowd;

White - like an ivory statue -

I'll gaze at him... will rest my eye! $!^{30}$ ]

Although it was inspired by a specific event, or rather a unique and tragic tangle of events, Norwid's Modlitwa does not belong to the category of occasional literature. The poet resists excessively clear and literal rendering of facts by adopting a method that belongs in the repertoire of his basic techniques, namely that of concealment, i.e. leaving something unsaid. ${ }^{31}$ The tight, dynamic and self-

${ }^{28}$ This perspective does not negate the deeper relation between certain Islamic or Arabic themes in this piece and the outside realities brought forth by the parable. For example, in the text the noon prayer (held at noon in mosques in Islam) remains in an "active" relation (in terms of ideas) with the Christmas Mass in the Holy Cross Church, i.e. the summa celebrated on 25 December 1881 at noon. For more information on prayer and the mosque as its location see: J. DANECKI, Podstawowe wiadomości o islamie, Warszawa 2007, pp. 106-107, 132-136.

29 J. SŁowacki, Duma o Wacławie Rzewuskim, Dzieła, ed. J. Krzyżanowski, Wrocław 1959, vol. 1, p. 54.

${ }^{30}$ C. Norwid, Poems, translated from the Polish by Danuta Borchardt in collaboration with Agata Brajerska-Mazur, New York 2011, p. 35.

31 " [...] silence can often express more than speech. [...] Thus, silence, or passing something over (in practical terms), is beyond doubt a function of speech. [...] Still, there is a different kind of passing over $[\ldots]$ which can be discerned in every sentence, becoming the logical cause and thread of the following sentence. In this sense, what the second sentence says and expresses is what the 
contained story reaches, in the last paragraph, a non-story-like, reflective counterpoint whose meaning emerges fully only when readers reconstruct something that the poet merely suggested. Concealment of this kind marks the following sentence: "Przypadku żadnego być nie mogło w domu modlitwy [...]" [Nothing can happen by chance in the house of prayer]. Readers aware of the "accident" in the Holy Cross Church and its consequences can relate the moral message to a specific event. Conversely, it seems that a "late grandson," who knows nothing about the disastrous coincidences of the Viennese fire and the Warsaw riots, can read Norwid's parable as communicating a universal truth. ${ }^{32}$

In his lectures on Słowacki, Norwid writes that "parables are characterised by the fact that they present not only the truth but also the drama of life that shapes this truth [...]" and that "there is only a certain layer or aspect of the truth that can be ideally represented and explained exhaustively through thought forms; full truth, however, needs the drama of life - parable - in order to emerge." (PWsz VI, 433).

Norwid did not discern in the report from "Kurier" any mention of the police being passive during these events. The three-day riot was presumed by many contemporaries to be a Tsarist provocation meant to demonstrate to the European public opinion - which was appalled at the Russian pogroms - that Poles also "beat up Jews." The once acute exposer of the police in all its forms ("policji tajnych, widnych i dwu-płciowych" [Police - covert, overt, of both sexes ${ }^{33}$ ] as he puts it in "Siła ich. Fraszka" [Their Power. An Epigram]) would now - towards the end of his life - seek the reasons behind tragedies like the intertwined ones in Warsaw and Vienna elsewhere, i.e. in the heart of humanity being open wider to the "world" than to God. This is the message of Norwid's parable.

Norwid was not the only writer who responded to the Warsaw events. During the pogrom, Konopnicka wrote three poems under the shared title Modlitwy ["Prayers"], which were rejected by publishers during her life. Wiktor Gomulicki

first remained silent about; similarly, what the third sentence says in fact constitutes what the second one passed over, the same with the third and the fourth, and so on and so forth... till the bottom of the message, which is exhausted only in this way, on the ground of this logic, in the process of this tangible unfolding." C. NorwID, Milczenie, PWsz VI, 231, 232.

${ }^{32}$ Modlitwa can be described as an "invisible metaphor" (cf. Ł. NiEwCZAS, Niewidoczna metafora. Strategie mówienia przenośnego w poezji Norwida, Lublin 2013) or as using the category of silence or passing over (see, e.g.: J. PuZynina, 'Milczenie'Norwida, [in:] Semantyka milczenia. Zbiór studiów. 2, Warszawa 2002, pp. 19-42; T. JERMALONEK, Kulturowe źródła Norwidowego 'milczenia'. Kilka uwag o jednym z ostatnich utworów Cypriana Norwida, [in:] Norwid-spotkania kultur, ed. E. Chlebowska, Lublin 2015, pp. 265-281.

${ }^{33}$ C. Norwid, Poems, p. 95. 
published the poem Gtos zelizonego [Voice of the Abused] in the press. Within several weeks, Orzeszkowa wrote and published a longer piece titled $O \dot{Z} y d a c h$ $i$ kwestii żydowskiej [On Jews and the Jewish Question]. Prus described the Warsaw pogrom in Lalka [Doll]. Konopnicka returned this question again in Mendel Gdański, a short story about the pogrom. ${ }^{34}$ Norwid also tried to join the discussion in June 1882 with the article ' $Z$ ydy' $i$ mechesy, which addresses the deeper conditions underlying the fate of Jews in European history. ${ }^{35}$

\section{REFERENCES}

BURDZIEJ B., 'Lalka' Prusa o genezie pogromu warszawskiego (1881). Rekonesans problemu, [in:] Jubileuszowe „Żniwo u Prusa”, ed. Z. Przybyła, Częstochowa 1998, pp. 171-192.

BURDZIEJ B., Marii Konopnickiej Modlitwy po pogromie warszawskim 1881 roku, [in:] Maria Konopnicka. Nowe studia i szkice, eds. J.Z. Białek, T. Budrewicz, Kraków 1995, pp. 51-62.

BURDZIEJ B., Refleksja poetycka Wiktora Gomulickiego o Żydach po pogromie warszawskim 1881 roku, Acta UNC, Filol. Pol. 51 (1998), pp. 23-43

DANECKI J., Podstawowe wiadomości o islamie, Warszawa 2007.

GADAMSKA-SERAFIN R., Świat arabsko-muzulmański w dziełach Norwida. Inspiracje i źródła, [in:] Kulturowy wymiar twórczości Norwida, eds. J.C. Moryc, R. Zajączkowski, Lublin 2016, pp. 39-83.

GOMULICKI J.W., Metryki i objaśnienia, [in:] C. NORWID, Pisma wszystkie, ed. J.W. Gomulicki, vol. 7, Warszawa 1971.

GRZEGORZEK W., Dogmat Niepokalanego Poczęcia Najświętszej Maryi Panny. Rozprawa historyczno-dogmatyczna, Tarnów 1855.

Historische Bilder zu Ringtheater. Online: https://austriaforum.org/af/Bilder_und_Videos/Historische_Bilder_IMAGNO/Ringtheater. Accessed 25 January 2021.

NIEWCZAS Ł., Niewidoczna metafora. Strategie mówienia przenośnego w poezji Norwida, Lublin 2013.

PELCZAR J., Ziemia Święta i islam czyli Szkice z pielgrzymki do Ziemi Świętej, która w roku 1872 odbyt i opisat..., cz. 2: Islam, Lwów 1875.

[Reiff A.?], Kilka słów z powodu warszawskich rozruchów, "Kurier Paryski”, no. 9 (15 January 1882), pp. 2-3.

${ }^{34}$ See: B. BuRDZIEJ, Marii Konopnickiej Modlitwy po pogromie warszawskim 1881 roku, [in:] Maria Konopnicka: nowe studia i szkice, eds. J.Z. Białek, T. Budrewicz, Kraków 1995, pp. 51-62; IDEM, Refleksja poetycka Wiktora Gomulickiego o Żydach po pogromie warszawskim 1881 roku, Acta UNC, Filol. Pol. 51 (1998), pp. 23-43; IDEM, 'Lalka' Prusa o genezie pogromu warszawskiego (1881). Rekonesans problemu, [in:] Jubileuszowe „Żniwo u Prusa”, ed. Z. Przybyła, Częstochowa 1998, pp. 171-192.

${ }^{35}$ See: M. InGLOT, Nad artykułem Cypriana Norwida 'Żydy i mechesy', "Prace Polonistyczne" 58 (2003), pp. 167-178. Inglot regards the Russian pogroms of 1881-1882 to constitute the foundation of Norwid's article and does not mention the one in Warsaw. See also: K. SAMSEL, Inwalida intencji. Studia o Norwidzie, Warszawa 2017, pp. 60-68. 
STROJNOWSKI S., Ziemia i jej mieszkańcy. Opisy malownicze krajów, ludów i obyczajów; z najcelniejszych autorów ojczystych i cudzoziemskich, oraz własnych prac, vol. 1, Warszawa 1881.

URBAŃSKI A., Prolog, wygłoszony na scenie lwowskiej dnia 19 grudnia 1881 podczas przedstawienia danego na rzecz ofiar pożaru w wiedeńskim Ringtheater, [in:] Utwory poetyczne, third edition, Lipsk 1884.

\section{$\mathrm{S}$ u m m a r y}

The article focuses on Modlitwa [Prayer], a short prose piece written by Cyprian Norwid towards the end of his life. The phrase "pod wrażeniem Teatru wiedeńskiego" ["under the impression of the Viennese theatre"] is read here as an indication that, despite the Arab setting, the plot and other elements of this piece draw on three tragic events directly preceding its composition in January 1882: the fire at the Ringtheater on 8 December 1881 and two events in Warsaw: the panic in the Holy Cross Church during Christmas Mass on 25 December, and the three-day-long pogrom of the Jewish community on 25-27 December. Uncovering these contexts, as suggested by Norwid, makes it possible to interpret Modlitwa as a parable which, by criticizing secularization, shows the way towards God and the fullness of prayer.

Keywords: Cyprian Norwid; Romantic literature; literature and history; literary parable; literary prayer; Ringtheater; Vienna; pogrom; Warsaw pogrom of Jews in 1881; Islam in literature; Kaaba in literature; Muslim rosary in literature.

BOGDAN BURDZIEJ is a historian of literature and professor at the Mikołaj Kopernik University in Toruń. He is author of the following books: Inny świat ludzkiej nadziei. „, Szkice” Adama Szymańskiego na tle literatury zsylkowej (1991); Super flumina Babylonis. Psalm 136(137) w literaturze polskiej XIX i XX wieku (1998); Izrael i krzyż. Tematy żydowskie w literaturze polskiej XIX wieku (2014). He co-edited the monographs Zygmunt Krasiński - nowe spojrzenia (2001), Poezja i astronomia (2006), Sienkiewicz dzisiaj. Formy (nie)obecności (2010), Italia. Inspiracje włoskie w literaturach stowiańskich (special issue of the journal Litteraria Copernicana, 2011), Wiktor Gomulicki znany i nieznany (2012); Profesor - Pamięci Artura Hutnikiewicza (special issue of the journal Litteraria Copernicana, 2016) and edited the following books: A. Szymański, Szkice (1998); F. Łasiewicki, Pamiętniki Woźnego Cenzury (1995); F. Jaskólski, Pasterze na Bachorzy. Sielanki kujawskie (2005). 